\title{
Front Matter: Volume 10751
}

, "Front Matter: Volume 10751," Proc. SPIE 10751, Optics and Photonics for Information Processing XII, 1075101 (21 September 2018); doi:

$10.1117 / 12.2514596$

SPIE Event: SPIE Optical Engineering + Applications, 2018, San Diego, California, SPIE. United States 


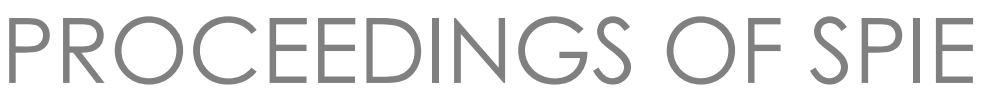

\title{
Optics and Photonics for Information Processing XII
}

\author{
Abdul A. S. Awwal \\ Khan M. Iffekharuddin \\ Mireya García Vázquez \\ Andrés Márquez \\ Víctor H. Diaz-Ramirez \\ Editors
}

19-20 August 2018

San Diego, California, United States

Sponsored and Published by SPIE

Volume 10751 
The papers in this volume were part of the technical conference cited on the cover and title page. Papers were selected and subject to review by the editors and conference program committee. Some conference presentations may not be available for publication. Additional papers and presentation recordings may be available online in the SPIE Digital Library at SPIEDigitalLibrary.org.

The papers reflect the work and thoughts of the authors and are published herein as submitted. The publisher is not responsible for the validity of the information or for any outcomes resulting from reliance thereon.

Please use the following format to cite material from these proceedings:

Author(s), "Title of Paper," in Optics and Photonics for Information Processing XII, edited by Abdul A. S. Awwal, Khan M. Iftekharuddin, Mireya García Vázquez, Andrés Márquez, Víctor H. Diaz-Ramirez, Proceedings of SPIE Vol. 10751 (SPIE, Bellingham, WA, 2018) Seven-digit Article CID Number.

ISSN: 0277-786X

ISSN: 1996-756X (electronic)

ISBN: 9781510620735

ISBN: 9781510620742 (electronic)

Published by

SPIE

P.O. Box 10, Bellingham, Washington 98227-0010 USA

Telephone +1 3606763290 (Pacific Time) · Fax +1 3606471445

SPIE.org

Copyright @ 2018 , Society of Photo-Optical Instrumentation Engineers.

Copying of material in this book for internal or personal use, or for the internal or personal use of specific clients, beyond the fair use provisions granted by the U.S. Copyright Law is authorized by SPIE subject to payment of copying fees. The Transactional Reporting Service base fee for this volume is $\$ 18.00$ per article (or portion thereof), which should be paid directly to the Copyright Clearance Center (CCC), 222 Rosewood Drive, Danvers, MA 01923. Payment may also be made electronically through CCC Online at copyright.com. Other copying for republication, resale, advertising or promotion, or any form of systematic or multiple reproduction of any material in this book is prohibited except with permission in writing from the publisher. The CCC fee code is 0277$786 \mathrm{X} / 18 / \$ 18.00$.

Printed in the United States of America.

Publication of record for individual papers is online in the SPIE Digital Library.

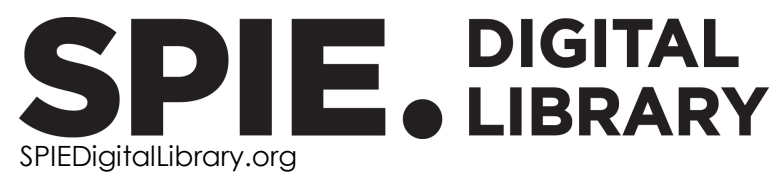

Paper Numbering: Proceedings of SPIE follow an e-First publication model. A unique citation identifier (CID) number is assigned to each article at the time of publication. Utilization of CIDs allows articles to be fully citable as soon as they are published online, and connects the same identifier to all online and print versions of the publication. SPIE uses a seven-digit CID article numbering system structured as follows:

- The first five digits correspond to the SPIE volume number.

- The last two digits indicate publication order within the volume using a Base 36 numbering system employing both numerals and letters. These two-number sets start with 00, 01, 02, 03, 04, 05, 06, 07, 08, 09, OA, OB ... 0Z, followed by 10-1Z, 20-2Z, etc. The CID Number appears on each page of the manuscript. 


\title{
Contents
}

\author{
vii Authors \\ ix Conference Committee \\ xi Introduction
}

SESSION 1 IMAGING TECHNIQUES AND PROCESSING

$1075102 \quad$ Stereo matching using adaptive windows and correlation filtering [10751-2]

$1075103 \quad$ A visual wikipedia for satellite imagery [10751-3]

\section{SESSION 2 HOLOGRAPHY AND DEVICES}

1075105 Optimized random phase only holograms in the Fresnel domain [10751-5]

$1075106 \quad$ Versatile simplified physical model for parallel aligned liquid crystal devices [10751-6]

$1075107 \quad$ Spectral imaging with a single pixel camera [10751-7]

$1075108 \quad$ Optical systems for task-specific compressive classification [10751-8]

1075109 The future of short-range high-speed data transmission: printed polymer optical waveguides (POW) innovation, fabrication, and challenges [10751-9]

\section{SESSION $3 \quad$ OPTICAL COMPUTING AND PHOTONIC SYSTEMS}

10751 OB Multiresolution analysis signal in a three beam path Mach-Zehnder interferometer based on a discrete wavelet transform [10751-11]

10751 OD Hybrid optical integrator based on silicon-on-insulator platform [10751-13]

10751 OE Machine learning application for silicon photonics transceiver testing [10751-14] 
10751 OF Learning and estimating whole sky visible, VNIR, SWIR radiance distributions from a commercial camera [10751-15]

$107510 G \quad$ Computational analysis of stress map variations by industrial light sources and load additions in digital photoelasticity [10751-16]

$10751 \mathrm{OH} \quad$ Homography estimation for camera document scanning applications [10751-17]

$10751 \mathrm{Ol} \quad$ Investigation of influence of illumination in a latent fingerprint acquisition system based on a smartphone [10751-18]

10751 OJ Research on active polarization-based target detection on sea surface [10751-19]

\section{SESSION 5 NEURAL NETWORKS AND MACHINE LEARNING}

10751 OK Recent experience with computational modeling for medical image analysis (Invited Paper) [10751-29]

10751 ON Active learning with deep Bayesian neural network for laser control [10751-22]

$1075100 \quad$ Visual tracking with kernelized correlation filters based on multiple features [10751-23]

\section{SESSION $6 \quad$ ALGORITHMS AND DETECTION}

$107510 Q \quad$ Human vision perceptual color based semantic image retrieval with relevance feedback [10751-25]

10751 OR Image processing strategies and multiple paths toward solutions [10751-26]

10751 OS Optimization of the keypoint density-based region proposal for R-CNN [10751-27]

10751 OT Image inpainting using Wasserstein Generative Adversarial Network [10751-28]

SESSION 7 DIGITAL IMAGE PROCESSING AND ENCRYPTION

10751 OV Asymmetric cryptosystem using double random-decomposition in fractional Fourier transform domain [10751-31]

10751 OW Cryptanalysis on double random phase encoding with deep learning [10751-32]

iv 
10751 OX 3D+T motion analysis: motion sensor network versus multiple video cameras [10751-33]

10751 oY Detection of change of thickness in transparent flat glass by means of "Time of Flight Distortion" from RGBD data [10751-34]

$107510 Z \quad$ Video processing in real-time in FPGA [10751-35]

1075111 A spatio-temporal deep learning approach for human action recognition in infrared videos [10751-48]

\section{POSTER SESSION}

1075112 Anamorphic characterization of a PA-LCoS based holographic data storage system [10751-37]

1075113 Graph-analytic technique for data routing in nonlinear holographic associative memories [10751-38]

$1075114 \quad$ Non-generated on wave length double phase conjugation based on second-order static holograms [10751-39]

1075116 Differentiating the phase structures of doughnut-like beams with similar intensity envelopes [10751-41]

$1075117 \quad$ Engineering solutions and synthesis of optics for visualization systems of light microscopes [10751-42]

$1075118 \quad$ Code system with increased security [10751-43]

1075119 Design and simulation of array cells for image intensity transformation and coding used in mixed image processors and neural networks [10751-44]

10751 1A Application of blockchain technologies for secure information management [10751-45]

10751 1B Application of cognitive systems to data sharing in Cloud Computing [10751-46]

10751 1C Towards an optimal bag-of-features representation for vehicle type classification in thermal infrared imagery [10751-47] 
Proc. of SPIE Vol. 10751 1075101-6

Downloaded From: https://www.spiedigitallibrary.org/conference-proceedings-of-spie on 25 Apr 2023 Terms of Use: https://www.spiedigitallibrary.org/terms-of-use 


\section{Authors}

Numbers in the index correspond to the last two digits of the seven-digit citation identifier (CID) article numbering system used in Proceedings of SPIE. The first five digits reflect the volume number. Base 36 numbering is employed for the last two digits and indicates the order of articles within the volume. Numbers start with 00, 01, 02, 03, 04, 05, 06, 07, 08, 09, 0A, OB...0Z, followed by 10-12, 20-2Z, etc.

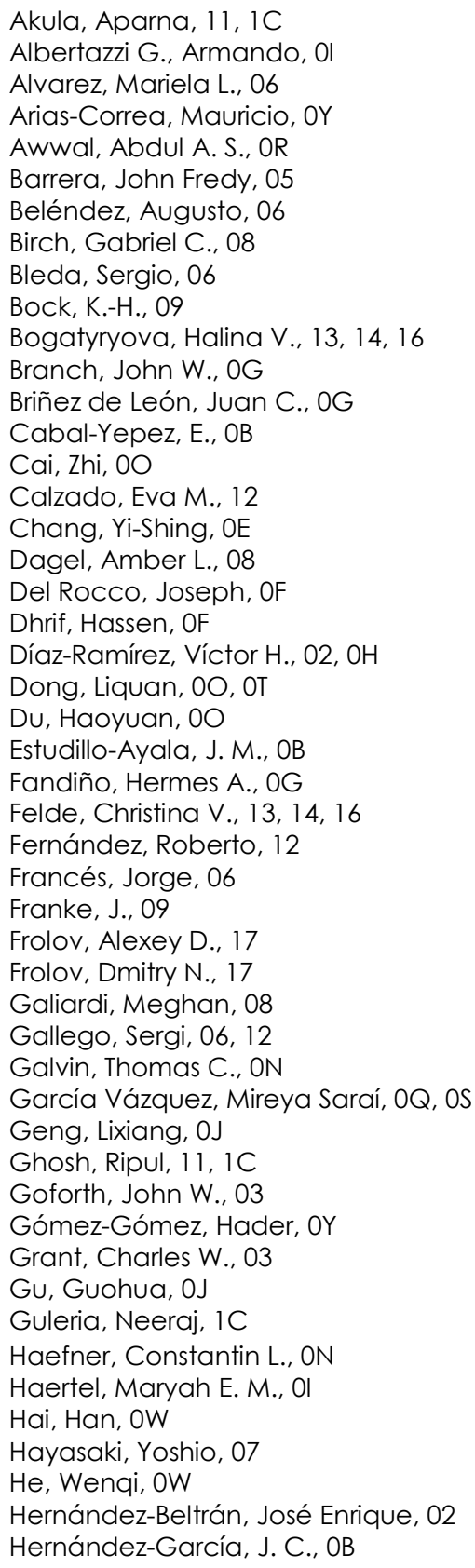

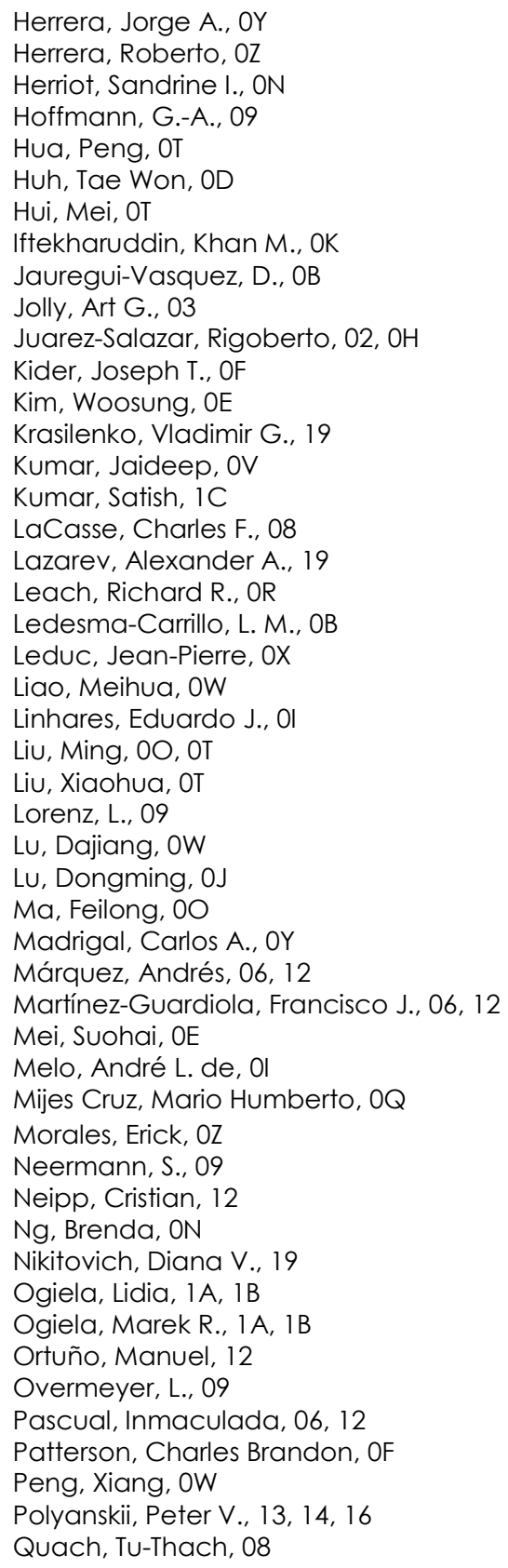


Ramírez Acosta, Alejandro, OQ, OS

Ray, Will R., 03

Reitberger, T., 09

Restrepo M., Alejandro, OG

Roberts, Randy S., 03

Rodríguez Espejo, Luis, OS

Rojas-Laguna, R., OB

Sardana, H. K., 1C

Sato, Ryo, 07

Seng, Yeoh Hoe, OE

Shah, Anuj K., 11

Shboul, Zeina A., OK

Siahmakoun, Azad, OD

Siders, Craig W., ON

Sierra Hernandez, J. M., OB

Silva-Alvarado, E. C., OB

Singh, Phool, OV

Sistrunk, Emily F., ON

Spinka, Thomas, ON

Stoll, T., 09

Strynadko, Myroslav T., 18

Talathi, Sachin S., ON

Torroba, Roberto, 05

Velez Zea, Alejandro, 05

Vinogradova, Olga A., 17

Weinert, George F., 03

Williams, Wade H., ON

Wolter, K.-J., 09

$\mathrm{XU}$, Jiang, OJ

Yadav, A. K., OV

Yuan, Ruifeng, 00

Zhao, Yuejin, 0O, OT 


\title{
Conference Committee
}

\author{
Program Track Chair
}

José Sasián, College of Optical Sciences, The University of Arizona (United States)

Conference Chairs

Abdul A. S. Awwal, Lawrence Livermore National Laboratory (United States)

Khan M. Iftekharuddin, Old Dominion University (United States)

Mireya García Vázquez, Centro de Investigación y Desarrollo de Tecnología Digital (Mexico)

Conference Co-Chairs

Andrés Márquez, University de Alicante (Spain)

Víctor H. Diaz-Ramirez, Centro de Investigación y Desarrollo de Tecnología Digital (Mexico)

Conference Program Committee

Md. Zahangir Alom, University of Dayton (United States)

George Barbastathis, Massachusetts Institute of Technology (United States)

Juan Campos, Universitat Autònoma de Barcelona (Spain)

Liangcai Cao, Tsinghua University (China)

Xinbin Cheng, Tongji University (China)

Laurence G. Hassebrook, University of Kentucky (United States)

Kazuyoshi Itoh, Osaka University (Japan)

Rigoberto Juarez-Salazar, Centro de Investigación y Desarrollo de Tecnología Digital (Mexico)

Mohammad Ataul Karim, University of Massachusetts Dartmouth (United States)

Richard R. Leach Jr., Lawrence Livermore National Laboratory (United States)

Byoungho Lee, Seoul National University (Korea, Republic of)

Abhijit Mahalanobis, Lockheed Martin Missiles and Fire Control (United States)

Mohammad A. Matin, University of Denver (United States)

Osamu Matoba, Kobe University (Japan)

Alastair D. McAulay, Lehigh University (United States)

Nasser M. Nasrabadi, U.S. Army Research Laboratory (United States)

Mark A. Neifeld, The University of Arizona (United States) 
Takanori Nomura, Wakayama University (Japan)

Marek R. Ogiela, AGH University of Science and Technology (Poland)

Ting-Chung Poon, Virginia Polytechnic Institute and State University (United States)

Philippe Réfrégier, Institut Fresnel (France)

Joseph Rosen, Ben-Gurion University of the Negev (Israel)

John T. Sheridan, University College Dublin (Ireland)

Jun Tanida, Osaka University (Japan)

Cardinal Warde, Massachusetts Institute of Technology

(United States)

Eriko Watanabe, The University of Electro-Communications (Japan)

Toyohiko Yatagai, Utsunomiya University (Japan)

María J. Yzuel, Universitat Autònoma de Barcelona (Spain)

\section{Session Chairs}

1 Imaging Techniques and Processing

Andrés Márquez, Universidad de Alicante (Spain)

2 Holography and Devices

Abdul A. S. Awwal, Lawrence Livermore National Laboratory (United States)

3 Optical Computing and Photonic Systems

Khan M. Iftekharuddin, Old Dominion University (United States)

4 Imaging Technologies and Applications

Andrés Márquez, Universidad de Alicante (Spain)

5 Neural Networks and Machine Learning

Abdul A. S. Awwal, Lawrence Livermore National Laboratory (United States)

6 Algorithms and Detection

Víctor H. Diaz-Ramirez, Centro de Investigación y Desarrollo de Tecnología Digital (Mexico)

7 Digital Image Processing and Encryption

Richard R. Leach Jr., Lawrence Livermore National Laboratory (United States)

8 Digital Image Processing and Systems

Víctor H. Diaz-Ramirez, Centro de Investigación y Desarrollo de Tecnología Digital (Mexico) 


\title{
Introduction
}

The conference of Optics and Photonics for Information Processing celebrated this year its twelfth edition in such an excellent venue as the Convention Center in San Diego. Evolution and new trends in this field are closely reflected in the presentations being delivered every year. We thank both the old and new presenters who decided to share their latest results in this conference with engaging enthusiasm! It was interesting see some insurgence of the optical computing research.

This year more than 40 presentations have composed the program of the conference. It consisted of two intensive days during which we had a very fruitful time sharing with authors and large number of audiences in a very lively and creative atmosphere. The topics covered by the conference are organized in eight sessions in the subjects of Imaging Techniques and Processing, Holography and Devices, Optical Computing and Photonic Systems, Imaging Technologies and Applications, Neural Networks and Machine Learning, Algorithms and Detection, Digital Image Processing and Encryption, Digital Image Processing and Systems. Just from these titles we appreciate the very diverse range of areas actually involved in Optics and Photonics for Information Processing.

Next year in San Diego, between 11-15 August 2019, we will have the opportunity to find out what have been, in the coming twelve months, the most appealing problems faced, and the original and innovative solutions proposed. We look forward to meeting both new and old colleagues and have in-depth and fruitful discussions with them. We must not forget to thank the SPIE staff for their excellent work not only during the conference but also before and after. And for the researchers, we wish you the best during this time and look forward to having you with us and share your latest results next year.

\author{
Abdul A. S. Awwal \\ Khan M. Iftekharuddin \\ Mireya García Vázquez \\ Andrés Márquez \\ Víctor H. Diaz-Ramirez
}


Proc. of SPIE Vol. 10751 1075101-12 Downloaded From: https://www.spiedigitallibrary.org/conference-proceedings-of-spie on 25 Apr 2023
Terms of Use: https://www.spiedigitallibrary.org/terms-of-use 